\title{
Utilization of Frozen Goat Semen with Addition Sweet Orange Essential Oil to Improve Genetic Quality in Ujung Teran Village
}

\author{
Sukma Aditya Sitepu ${ }^{1 *}$ and Julia Marisa ${ }^{2}$ \\ ${ }^{1)}$ Department of Animal Husbandry, Faculty of Sains and Technology, Universitas Pembangunan Panca \\ Budi, Medan 20122, Indonesia \\ ${ }^{2)}$ Department of Agroecotechnology, Faculty of Sains and Technology, Universitas Pembangunan Panca \\ Budi, Medan 20122, Indonesia
}

\begin{abstract}
One of the causes of underdeveloped goats is low genetic quality. The way that can be done to improve the genetic quality of goats is to do cross-breeding with superior goats through Artificial Insemination. The community service aims to increase the knowledge of goat farmers in Ujung Teran Village, Langkat Regency on how to make goat frozen semen using tris yolk extender plus sweet orange essential oil for Artificial Insemination program along with the benefits that can be obtained. The method of service is by giving lectures and training to goat farmers. The results obtained from the implementation of this program are that farmers know how to make frozen semen of goat using sweet orange essential oil on the tris yolk extender and are willing to make Artificial Insemination in their goat cattle.
\end{abstract}

Keywords: Artificial Insemination, Essential Oil, Frozen Semen, Goat, Sweet Orange

\begin{abstract}
Abstrak. Tujuan dari pelaksanan pengabdian kepada masyarakat ini adalah melakukan pengenalan kepada masyarakat tentang analisis pendapatan usaha susu kambing peranakan etawa untuk mengetahui mengetahui besarnya pendapatan peternak susu kambing peranakan etawa pada berbagai skala tingkat kepemilikan ternak di Desa Payageli Kabupaten Deli Serdang. Pelaksanaan pengabdian masyarakat ini diharapkan dapat meningkatkan kemampuan dan pengetahuan peternak usaha susu kambing peranakan etawa di Desa Payageli Kabupaten Deli Serdang untuk menganalisis sendiri tentang bagaimana memisahkan antara komponen penerimaan dan komponen biaya yang akan dikeluarkan dalam satu periode pemeliharaan sehingga memudahkan mereka untuk dapat menghitung seberapa besar total pendapatan yang mereka hasilkan dalam satu periode pemeliharaan ternak kambing Peranakan Etawa, yang akhirnya dapat meningkatkan
\end{abstract}

*Corresponding author at: Jalan. Gatot Subroto KM 4.5 Medan 20122, Indonesia

E-mail address: sukmaaditya@dosen.pancabudi.ac.id 


\begin{abstract}
kesejahteraan peternak tersebut. Adapun hasil yang diperoleh dari pelaksanaan program ini terlihat beberapa peternak sudah memahami analisis pendapatan usaha susu Kambing Peranakan Etawa dan mulai memperhitungkan berapa pendapatan yang selama ini telah mereka peroleh sehingga mereka belajar mengefisiensikan biaya produksi usaha mereka agar pendapatan yang diperoleh meningkat.
\end{abstract}

Kata Kunci: Inseminasi, Minyak Esensial, Semen Beku, Kambing, Jeruk Manis Received 20 October 2018 | Revised 30 January 2019 | Accepted 14 February 2019

\title{
1. Introduction
}

Ujung Teran Village, Langkat District is a village with a large part of its population working as farmers. The community of Ujung Teran Village does goat breeding business with its maintenance system is still semi-intensive, namely by raising livestock only at night in the cage and in the morning until the evening grazing around the area's area. Low production and productivity of goat livestock are one of them because of the poor genetic quality of livestock.

The phenomenon is that the goat mating system in Ujung Teran Village still relies on natural mating that is carried out at the time of being grazed by allowing female goats to be free to mating goats which are not necessarily of good quality. This method has disadvantages such as low genetic quality because it comes from local goats, cannot record, the chance of inbreeding and high disease.

The purpose of community service is to increase the knowledge of goat breeders on how to make frozen semen using tris yolk extender and sweet orange essential oil. The of the research by Sitepu et al [1] show that sweet orange essential oil can improve the quality of frozen semen of Boer Goat. After the program is complete, it is expected that farmers will be willing to make Artificial Insemination on their goats by using Tris Yolk Extender and Sweet Orange Essential Oil to improve the genetic quality of goats in Teran Village.

\section{Method}

The approach method that is given is to do service by giving:

Lectures and Discussion. Lecture material was given to participants. After finishing the lecture followed by discussion. Lecture materials are: 
- Types of superior goats

- Benefits and advantages of Artificial Insemination of goats.

- Percentage of research results of frozen semen of Boer goats using essential oils

- Making frozen goat semen

- Evaluation /quality test of frozen goat semen

- The practice of making frozen semen and implementing Artificial Insemination.

\section{Procedure}

Work procedures to support the realization of the solutions offered, then first make an initial observation in the field approach through interviews and find the phenomenon of problems. After observation and socialization, a study of the problem was carried out and found the solution to be offered, then prioritized the implementation stages and then did the service by providing counseling and practice. The last is to evaluate the results by observing the results of the activities that have been carried out.

\section{Result and Discussion}

From the results of the programs that have been carried out in the community service in Ujung Teran Village, it is known that there have been several impacts of changes towards a better direction in accordance with the explanation of the results.

\section{Analyze changes in the mindset of farmers regarding Artificial Insemination}

At first, the goat breeders did breeding by natural mating. However, after the Community Services through lectures and discussions, Farmers began to think to turn to artificial insemination. Farmers are interested in switching to Artificial Insemination since being given counseling about the potential of male studs from superior livestock that have various advantages such as large body weight and rapid growth. Farmers want to after the Artificial Insemination will be obtained good genetic goats that inherit superior traits.

One of the reasons why farmers are reluctant to do Insemination is because according to the artificial insemination is difficult, limited facilities are needed and low success rates. Many factors cause the high risk of failure of Artificial Insemination such as the quality of frozen goat semen, the process of Artificial Insemination implementation and inseminator skills [2]. 
Community Service that has been carried out, given counseling on the procedures for implementing and handling the Goat Artificial Insemination program. It is expected that after knowing these procedures, farmers can understand and actively monitor their livestock during the Artificial Insemination program so that if an error occurs, it can be solved immediately so that the percentage of success increases.

Analysis of understanding of the advantages, benefits, and method of making goat frozen semen using sweet orange essential oil in the tris yolk extender. Through counseling and training that has been carried out, goat farmers have known the superiority of frozen goat semen using sweet orange essential oil in the tris yolk extender, namely the increased quality of semen obtained. Sitepu, et. al., [1] research on frozen semen shows the occurrence of quality improvement after motility, viability, membrane integrity and, acrosome integrity. Farmers also understand how to make goat frozen semen from preparation, dilution of semen, freezing to storage. Farmers know some of the benefits gained from making Artificial Insemination.

The selling price of goats produced is far more expensive because it comes from superior goats that improve genetic quality when compared to natural mating which only produces poor quality goats because it is obtained from local goat sperm in the field. In addition, we can also regulate the birth spacing which is more efficient so that farmers do not experience losses in livestock raising [3]. Related to this, some farmers claim to be more interested in breeding than goat fattening.

The goatling obtained have great body weight and rapid growth results in greater profits than natural mating [4]. To obtain maximum benefits, it is necessary to provide more costs such as the cost of implementing the Artificial Insemination program and the purchase of good quality feed [5]. However, if it is confronted with an increase in the selling price of goats because of the increase in genetic quality and high body weight, it will result in greater profits for goat livestock business [6]. 


\section{Conclusion}

1. There is a change in the perception of goat farmers towards Artificial Insemination. Farmers have realized that doing Artificial Insemination will improve the genetic quality of livestock produced while increasing the profits of goat livestock business.

2. Goat farmers have known the advantages, benefits, and methods of making goat frozen semen using sweet orange essential oil in the tris yolk extender and want to do Artificial Insemination.

\section{References}

[1] Sitepu, S.A. and Zaituni, U., 2018. Improved quality of frozen boer goat semen with the addition of sweet orange essential oil on tris yolk and gentamicin extender. In IOP Conference Series: Earth and Environmental Science 122 (1) : 012125 .

[2] Toelihere, M. R. 1993. Fisiologi Reproduksi pada Ternak. IPB Press, Bogor.

[3] Fauzia, L., and H. Tampubolon., 1991. Pengaruh Keadaan Sosial Ekonomi Petani Terhadap Keputusan Petani Dalam Penggunaan Sarana Produksi. Universitas Sumatera Utara Press, Medan.

[4] Hafez, E. S. E., and B. Hafez. 2005. Reproduction in Farm Animal 7 th ed. Lippincott Williams and Walkins, South Carolina.

[5] Blakely, J., and D. H. Bade., 2008. Ilmu Peternakan. Gadjah Mada University Press, Yogyakarta.

[6] Cyrilla, L. and Ismail. A., 1998. Usaha Peternakan. Diktat Kuliah. Jurusan Sosial Ekonomi. Fakultas Peternakan. Institut Pertanian Bogor, Bogor. 